phantasm a quarter-century later. Much of the world shows signs of sliding into yet another round of right wing paranoia, this time feeding upon Islamophobia, xenophobia, and racism. Gullible voters are given bogus assurances that corporatebased politics - especially in the US — will see them through crises like climate change and economic disparity generated and driven by the very same global megacompanies that manipulate their respective political systems. This is reported, willingly and uncritically, by corporate-controlled media in countries visibly transitioning from representative democracies to plutocratic oligarchies.

Deery might have mentioned that the CPUSA's moderate leadership during WWII came to an end with the shift toward pro-Stalin hardliners in 1945. That left many members far more vulnerable when the combined "anti-Red" forces of the (e.g.) FBI, Congressional Committees, Smith Act, and Blacklist "engulfed the political culture with a virulent strain of bigotry and intolerance toward leftists and nonconformists." (6) Deery wisely avoids seeing parallels with totalitarianism in any other country. Except for atomic spy Julius Rosenberg (and his innocent wife), no one in the USA was executed. Nor were the US's federal prison camps comparable to the Soviet or Chinese long-term detention settlements. By the late 1960s even the last vestiges of McCarthyism in Hollywood had expired. But similar reactionary forces are always at play. Given the right circumstances they can quickly resurface. Deery's Red Apple reminds us that it is fear, as much as force, that can initiate and direct - and ultimately sustain - repression and tyranny.

Henry Innes MacAdam

DeVry University

\title{
Peter Kulchyski, Aboriginal Rights Are not Human Rights: In Defence of Indigenous Struggles (Winnipeg: ARP Books, 2013). 176 pp. \$19.95 Paperback.
}

In Aboriginal Rights Are not Human Rights, Peter Kulchyski argues that resolutions such as the United Nations Declaration on the Rights of Indigenous Peoples produce a "conceptual confusion" between human rights and Aboriginal rights. Whereas human rights developed in conjunction with the Western state and protect purportedly universal human characteristics, Aboriginal rights originate in Aboriginal peoples' struggles over land and to protect traditional cultural practices. When the United Nations or Amnesty International fail to distinguish between Aboriginal and human rights, they ignore the concerns of Aboriginal peoples such as self-determination.

The book addresses three distinct features of Aboriginal rights: cultural traditions; struggles with the state over land; and rights in practice. In the first section, Kulchyski positions the land-based struggles of Aboriginal peoples within a Marxist framework. Aboriginal peoples have a mode of production based on hunting and gathering, and their cultural practices and social structures emerge from 
this relationship to the land. Aboriginal economies are not based on industrial labour and Marxist analyses should not frame Aboriginal peoples as part of the working class. The following section provides historical context for this framework. It surveys past and contemporary conflicts between Aboriginal peoples and the Canadian state. From negotiation of the Numbered Treaties to Idle No More, nearly every struggle is an attempt by Aboriginal peoples to protect their land rights. The third section demonstrates how Aboriginal rights exist in practice. It provides five case studies in which Aboriginal communities attempt to prevent exploitation of the land by the government, corporations, or both. For example, hydro development in northern Manitoba damages the landscape so badly that Aboriginal peoples can no longer hunt or fish. Aboriginal peoples can express their rights only when able to practice cultural traditions such as hunting and fishing, and the destruction of land critically undermines that ability.

Kulchyski is particularly concerned with cultural difference. Somewhat ironically, he uses the notion of difference to challenge liberal ideology. Liberalism is, at its core, a philosophy of difference. It aspires to a universal political or economic system, but to do so it must encompass a diversity a peoples and groups with conflicting worldviews. Thus, liberalism views cultural difference as a problem that must be confined and governed. But for Kulchyski, cultural difference emerges from the interaction between people and place. People have different needs based on the unique environment in which they live. As they adapt to a unique set of environmental conditions, they develop different social and cultural practices. For example, Kulchyski contends that an agricultural lifestyle requires hierarchical social structures whereas a hunting and gathering lifestyle produces relational social patterns. Cultural difference is therefore not a problem to be constrained. Rather, it is a solution to the fact that people live in many different social and environmental contexts.

The most critical element of Kulchyski's argument is that Aboriginal rights exist performatively, unlike human rights which exist categorically. Western knowledge relies upon categories, and the use of categories can reproduce colonial power relations. Racism is founded on the categorization and comparison of humans by western scientists. A cursory glance at this book may give the reader the impression that human rights and Aboriginal rights are two separate categories. This, however, would be a serious misreading. Human rights are categorical in that one possesses them by virtue of their membership to a particular category of person, for example women or unionists. But Aboriginal rights are rooted in the particular practices of a unique people. One has Aboriginal rights by virtue of the fact that they actively participate in certain traditional and cultural practices, not because they have Indian status. One might more meaningfully view Aboriginal rights in relation to rights such as language which exist only insofar as a community can engage in certain practices without restriction.

Is it a useful practice to distinguish between Aboriginal rights and human 
rights? There is very little Canadian literature on Aboriginal peoples and human rights, and this book helps to explain why: the relationship between Aboriginal and human rights is inadequately defined. Kulchyski takes the first step towards clarifying this relationship by identifying what distinguishes Aboriginal rights from human rights. The distinction highlights that the struggles of Aboriginal peoples differ from those of other marginalised peoples such as women or religious minorities. Aboriginal struggles are against a colonial state that uses rights to further its colonial project. Kulchyski does not outright reject the value of human rights, but simply asks us to view them as a practice and find the particular contexts in which they are useful.

This book is essential reading for scholars working in human rights or native studies. The content itself is not particularly new, although the third section presents several case studies based on Kulchyski's own research. What makes it unique is the framing of this content. The book is essential for scholars because it forces the reader to question some deeply entrenched beliefs about human rights. Of course, many will not welcome this shift in thinking. A more receptive audience however will be Indigenous activists and non-Indigenous allies looking to transform capitalist and colonialist systems. Kulchyski has deeply Marxist ideals and correspondingly revolutionary intentions. He inspires the reader to action by demonstrating that there is real need for change and providing some possible pathways towards it.

Jason Chalmers

University of Alberta

\section{Sulaiman H. Al-Farsi. Democracy and Youth in the Middle East: Islam, Trib- alism and the Rentier State in Oman (London: I.B. Tauris, 2013). 320 pp. $\$ 99.00$ Hardcover.}

The contemporary history of Oman may be said to have begun in 1970 when Sultan Qaboos replaced his father as ruler and set the country firmly on the path to socioeconomic development and to political evolution. Oil provided the means for the former while the course of the latter was principally determined by the personality and vision of the present sultan, still in power some 45 years later. The Sultanate of Oman is unquestionably an authoritarian state but most would agree that it has a benevolent ruler and that its people believe that the existing system is legitimate. But two relevant qualifications should be noted. First, the throne must pass in the coming years to a new sultan and considerable uncertainty surrounds the process of succession. Second, as education and exposure to the outside world advances and deepens, younger Omanis may be increasingly discontent with the system as it presently exists.

In this book, apparently derived from a British PhD thesis, Sulaiman Al- 